\title{
Alternative mechanisms of charging for use of water resources in wastewater assimilation
}

\section{Mecanismos alternativos de cobrança pelo uso de recursos hídricos para assimilação de efluentes}

\author{
Amanda Rodrigues Moreira de Oliveira ${ }^{1}$, Alisson Carraro Borges ${ }^{1}$, Antonio Teixeira de Matos $^{2}$, \\ Demétrius David da Silva ${ }^{1}$ and Fernando Falco Pruski ${ }^{1}$ \\ ${ }^{1}$ Universidade Federal de Viçosa, Viçosa, MG, Brazil \\ ${ }^{2}$ Universidade Federal de Minas Gerais, Belo Horizonte, MG, Brazil \\ E-mails: amanda.moreira@ufv.br (ARMO), borges@ufv.br (ACB), atmatos@desa.ufmg.br (ATM),demetrius@ufv.br (DDS), \\ ffpruski@ufv.br (FFP)
}

Received: June 15, 2016 - Revised: September 09, 2016 - Accepted: October 13, 2016

\begin{abstract}
Nowadays in most hydrological basins in Brazil, the charging mechanism of water use for effluents assimilation in inland surface water bodies is based on the emitted organic load parameter quantified in terms of Biochemical Oxygen Demand (BOD). This method is insufficient given the broad variety and compositions of discharges. Therefore, the objectives of the study are to propose alternative charging mechanisms for the qualitative use of water resources, aiming to insert, beside BOD, other parameters as calculation criteria; and to evaluate the charging potential for the Doce River hydrological basin. Two methods were proposed: the Limiting Population Equivalent (LPE) and the Compromised/Committed Volume (CV). Five water quality parameters were established: Biochemical Oxygen Demand, Chemical Oxygen Demand, Total Suspended Solids, Ammonia Nitrogen, and Phosphorus. The proposed mechanisms contemplated, from a broader perspective, the real problem concerning water quality in the Doce River basin. Simulations showed that phosphorus was a problem of concern for managing water resources in the specific basin. The method of Limiting Population Equivalent was considered of easiest application and understanding by its users.
\end{abstract}

Keywords: Charging mechanism; Compromised/Committed volume; Population equivalent.

\section{RESUMO}

Atualmente, a cobrança pelo uso da água para fins de assimilação de efluentes é, na maioria das bacias hidrográficas brasileiras, baseada no cálculo da carga orgânica emitida, quantificada em termos da Demanda Bioquímica de Oxigênio (DBO). Trata-se de um método pouco abrangente considerando-se a variedade e composição dos efluentes comumente lançados. Assim, objetivou-se propor mecanismos alternativos de cobrança pelo uso qualitativo dos recursos hídricos, procurando-se a inserção de novos parâmetros, além da DBO, como critério de cálculo; e avaliar o potencial de arrecadação tomando-se como estudo de caso a bacia hidrográfica do rio Doce. Foram duas as propostas apresentadas: a do Equivalente Populacional Limitante (EPL) e a do Volume Comprometido (VC); estabelecendo-se a aplicação de 5 parâmetros de qualidade de água: Demanda Bioquímica de Oxigênio, Demanda Química de Oxigênio, Sólidos Suspensos Totais, Nitrogênio Amoniacal e Fósforo. Os mecanismos propostos contemplaram, de forma mais ampla, o real problema da qualidade das águas na bacia do Doce; e as simulações evidenciaram o fósforo como um problema preocupante para a gestão dos recursos hídricos na referida bacia. A proposta do Equivalente Populacional Limitante foi considerada a de mais fácil aplicação e entendimento pelos usuários.

Palavras-chave: Mecanismo cobrança; Volume comprometido; Equivalente populacional. 


\section{INTRODUCTION}

Despite the decreasing availability of fresh water in the world, it has been observed that the few available water sources are suffering from degradation by humans. The various actions such as increasing the discharge of urban and industrial pollution, inappropriate land use, agricultural inputs, water erosion, deforestation, and mining are the main responsible for the worsening water contamination situation (RIBEIRO et al., 2011), preventing or hindering their use for other purposes.

As qualitative aspects can lead to restrictions on water availability, quantity and quality should be treated inseparably for efficient management of water resources and practice of a sustainable development model (PINHEIRO et al., 2013). In Brazil, the landmark of water management is the Water Code, established by Decree number 24.643 of June 10, 1934. The importance of water from a quantitative point of view has been known since the end of the last century, while the recognition of the quality, despite its remarkable importance, was slow and gradual (CAMPOS; STUDART, 2001). Only since the end of the twentieth century with the enactment of Law number 9433 of January 8, 1997 was the concept of sustainable water resources planning clearly advocating the inseparability of the quantitative and qualitative aspects, recognizing the integrated management as one of the general action guidelines (RIBEIRO, 2007).

Thus, Law number 9.433/1997, also known as the "Water Law", was introduced in Brazil as a management tool. It charges for use, not only quantitative but also qualitative aspects of water in order to recognize its economic value, to encourage the conscious use with tendency to preserve and generate resources for repair and maintenance of water availability (BRASIL, 1997).

According to Silva (2006), charging for water use is discussed using different methodologies/formulations that seek to consider specific conditions of each region or watershed due to the large territory and the different regional realities. These are generally comprised of weighting coefficients, calculation bases - abstraction volumes, consumption or dilution and pollution loads - and unit values.

Even though the Doce River Basin Committee (CBH-Doce) has been the fourth federal committee to implement the charges for the quantitative and qualitative improvement of water conditions, the methodology regarding the charging for effluent assimilation is calculated based only on the relative parameter of organic load released, which is quantified in terms of biochemical oxygen demand (BOD). This method is not comprehensive enough to represent the variety and the composition of waste loads and thus, cannot be reliably depicting the volume of water compromised by various activities.

For these reasons, this study aimed to present proposals on alternative mechanism methods of charging for the use of water resources in assimilation of effluents, including additional parameters besides the BOD and evaluating storage potential by taking the Doce River watershed as a case study.

\section{AREA OF STUDY}

The Doce River Basin is located in the Southeast region, between parallels $17^{\circ} 45^{\prime}$ and $21^{\circ} 15^{\prime} \mathrm{S}$ and the meridians $39^{\circ} 30^{\prime}$ and $43^{\circ} 45^{\prime} \mathrm{W}$, which includes the river basin district of the southeast Atlantic. The basin covers 230 municipalities and a drainage area of approximately $86,715 \mathrm{~km}^{2}$. About $86 \%$ of its extent is within the state of Minas Gerais and the other $14 \%$ in the state of Espírito Santo (CONSÓRCIO ECOPLAN LUME, 2010) with a population of 3.5 million inhabitants (AMORIM et al., 2011).

The headwaters of the Doce River are located in the state of Minas Gerais in the mountains of Mantiqueira and Espinhaço, and its waters run about $850 \mathrm{~km}$ before reaching the Atlantic Ocean near the village of Regency in the state of Espírito Santo (Figure 1). There are two streams of federal dominion in the basin: the Doce River and the river José Pedro, a tributary of the Manhuaçu River (CONSÓRCIO ECOPLAN LUME, 2010).

Economic activity in the Doce River Basin is quite diverse, especially with respect to: agriculture (reforestation, traditional crops, coffee plantations, sugarcane, and dairy, beef, and swine farming); agribusiness (sugar and ethanol); mining (iron ore, gold, bauxite, manganese, precious stones and others); industry (pulp, steel, and dairy products); trade and services in support of industrial complexes; and the generation of electricity (CONSÓRCIO ECOPLAN LUME, 2010).

Within this context, the Doce River Basin was chosen because of its great socio-economic and political importance, because it is a basin with a lot of economic activity and a large population.

\section{METHODOLOGY}

\section{Definition of water quality parameters}

In development of alternative proposals for charging for water resource usage for assimilation of wastewater in the Doce River Basin, water quality data of the watershed study were used.

The information researched and used was obtained from the Integrated Plan for the Doce River Basin Water Resources (CONSÓRCIO ECOPLAN LUME, 2010), the technical report on the occurrence of cyanobacteria in the Doce River Basin (ANA, 2012a), and also in quarterly reports of "Minas Gerais Water Project", the Minas Gerais Institute of water Management (IGAM, 2013). IGAM has monitored the quality of surface and groundwater of Minas Gerais since 1997, generating data necessary for the management of water resources.

Thus, a review of water quality parameters was performed in order to identify those in disagreement with the limits established by the CONAMA Resolution number 357 on March 17, 2005 (CONAMA, 2005). This was done for the classes that are found in the water bodies of the Doce River Basin, so that they could define those most important to make alternative proposals.

Among the water quality parameters, the biochemical oxygen demand (BOD), chemical oxygen demand (COD), total suspended solids (TSS), ammonia nitrogen $\left(\mathrm{N}_{\text {ammonia }}\right)$, and total phosphorus $\left(\mathrm{P}_{\text {total }}\right)$ were the most relevant in application of alternative mechanisms for charging for water use to assimilate effluent in the Doce Basin - case study.

\section{Alternative mechanisms for charging}

The definition of the mechanisms and charging units used for the proposal preparations were based on the literature review for the pollutant load units practiced in other countries. The review put attention on the unit choice of better overall understanding for the users. Moreover, the national experience was considered 


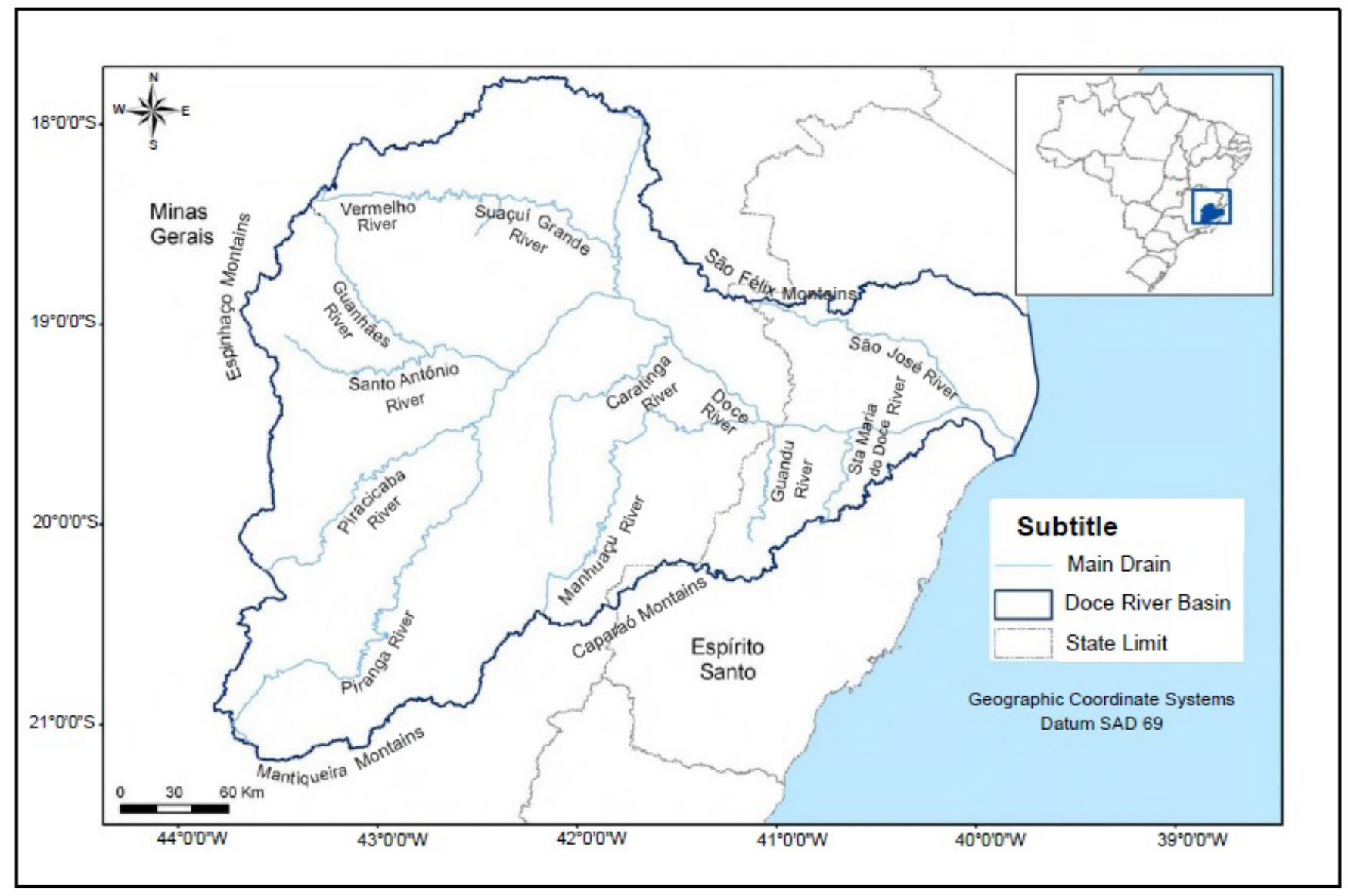

Figure 1. Map of the Doce River Basin. Adapted from Consórcio Ecoplan Lume (2010).

in charging for the assimilation of waste, taking advantage of comments made at Integration Technical Chamber of Doce Basin (CTI-Doce) meetings for users in sector.

Based on previous studies, they elaborated two alternatives proposed for use within the committees of the Brazilian basins charging water resource use: Limiting Population Equivalent (LPE) and Compromised/Committed Volume (CV).

The LPE proposal was based on the concept of equivalent population, i.e., theoretically, pollution generated by an inhabitant per day. Thus, each parameter considered in the proposal will have its load converted to the unit population equivalent (PE). The background load was discounted from existing load in the watercourse that came to the pickup point. PEs obtained for each parameter were defined by selecting one that would be "limiting", i.e., the parameter that provided the highest population equivalent to the charge given to that parameter. Equation 1 shows the procedure for calculating $\mathrm{PE}$ :

$$
\mathrm{PE}_{\text {parameter }}=\frac{\left(\mathrm{C}_{\mathrm{E}}-\mathrm{C}_{\mathrm{B}}\right) \times \mathrm{Q}_{\text {released }}}{\mathrm{LT}_{\text {parameter }}}
$$

In which,

$\mathrm{PE}_{\text {parameter }}=$ Population equivalent of a given parameter (inhab);

$\mathrm{C}_{\mathrm{E}}=$ Concentration of the parameter in the effluent $\left(\mathrm{kg} \mathrm{m}^{-3}\right)$;
$\mathrm{C}_{\mathrm{B}}=$ Prior "background" concentration of the parameter in the watercourse receiver $\left(\mathrm{kg} \mathrm{m}^{-3}\right)$;

$\mathrm{Q}_{\text {released. }}=$ Flowrate released by the enterprise $\left(\mathrm{m}^{3} \mathrm{yr}^{-1}\right) ; \mathrm{e}$

$\mathrm{LT}_{\text {parameter }}=$ Typical per capita load of the parameter in sewage $\left(\mathrm{kg}\right.$ inhab $\left.\mathrm{yr}^{-1}\right)$.

The previously proposed CV was based on the principle of dilution. The charging unit is the cubic meter of water that will be needed for assimilation of certain pollutant load so that it does not change the condition of the recipient course. Forgiarini et al. (2008a, b) made a model of charging for the use of water in the Santa Maria (RS) river basin also working with this method of charging. Just as in the PLA proposal, the "limiting" value of CV and a discount from the preexisting load in the watercourse in the pickup point was considered (background load of discount). Equation 2 shows the procedure for calculating $\mathrm{CV}$ :

$\mathrm{CV}=\frac{\left(\mathrm{C}_{\mathrm{E}}-\mathrm{C}_{\mathrm{B}}\right) \times \mathrm{Q}_{\text {released. }}}{\mathrm{C}_{\mathrm{L}}}$

In which,

$\mathrm{CV}=$ Committed/Compromised annual volume to dilute the pollution load $\left(\mathrm{m}^{3}\right)$;

$\mathrm{C}_{\mathrm{E}}=$ Concentration of the parameter in the effluent $\left(\mathrm{kg} \mathrm{m}^{-3}\right)$;

$\mathrm{C}_{\mathrm{B}}=$ Prior "background" concentration of the parameter in the watercourse receiver $\left(\mathrm{kg} \mathrm{m}^{-3}\right)$; 
$\mathrm{Q}_{\text {relesed }}=$ Flowrate released by the enterprise $\left(\mathrm{m}^{3} \mathrm{yr}^{-1}\right) ; \mathrm{e}$ $\mathrm{C}_{\mathrm{L}}=$ Concentration limit of the framework class for the watercourse receiver $\left(\mathrm{kg} \mathrm{m}^{-3}\right)$.

\section{Simulations}

Simulations on water charging were made for the sanitation sector with the implementation of alternative mechanisms to demonstrate the potential for water use charging in the Doce River Basin. The potential of charging was broken down at the state level, when the river is in the state domain, and at the federal level, when in federal domain.

For this, the current user interface data for charging were used. These include the released flow and the treated flow in addition to the concentration of the considered parameters for each (BOD, COD, TSS, $\mathrm{N}_{\text {ammonia }}$ and $\left.\mathrm{P}_{\text {total }}\right)$. Thus, the parameters referred to the pollutant load were defined with the data flow and concentration; then, the conversion was made using Equations 1 and 2 for such loads with the units to be charged, being the population equivalent (Equation 1) and the committed amount (Equation 2). The obtained units were multiplied by the value charged for Public Price per Unit (PPU), which will be defined later.

To run the simulations, a database provided by the National Water Agency (ANA) was used. It was obtained by the Integrated Environmental Information System (SIAM) of Minas Gerais, the enterprises, and users currently in charge (attended recovery in 2011/2012).

Influent flows and treated effluent flows were used. According to the types and degrees of wastewater treatment currently used in the basin, average removal efficiencies of pollutants were estimated in the effluent established from the literature (VON SPERLING, 2014). As there are few treatment initiatives of existing wastewater in the basin, it had no impediment to such estimates.

Databases usually used for the simulations of charging scenarios provided by ANA, IGAM, and other organizations generally have only quantitative data. The only available qualitative parameter is the biochemical oxygen demand (BOD) for historical reasons and also because the current model of charging only requires this parameter.

As explained in the proposed concept of Limiting Population Equivalent (LPE) and Compromised/Committed Volume (CV), in addition to quantitative data (volume of waste dumped annually), quality data is demanded (BOD, COD, ammonia nitrogen, total phosphorus and total suspended solids). Eventually, metal concentration data and biorecalcitrant organic compounds such as phenols and cyanides are demanded depending on the characteristic of the effluent released.

Article 9 of Normative Resolution CERH/COPAM-MG number 26 from December 18, 2008 establishes that users who are not subject to the process of Environmental Authorization of Operation (AAF) or environmental licensing by the state are exempted from obtaining grants for wastewater discharge. The respective River Basin Committee and the State Council of Water Resources $(\mathrm{CERH})$ can approve the use-setting criteria insignificant to sewage discharge, except for formally summoned enterprises by a managing body of water resources (CERH/COPAM-MG, 2008).

It is inferred, therefore, that all users who fit the Normative Deliberation COPAM number 74 from September 9, 2004, such as AAF or as EIA/RIMA, should make grant requests through the call notice or when the license revalidation are subject to recovery. On the other hand, users that are not present in this deliberation will be exempt.

Thus, the relative ease in obtaining such parameters -BOD, COD, TSS, $\mathrm{N}_{\text {ammonia }}$, and $\mathrm{P}_{\text {total }}$ - was initially noted - since the enterprises of the Doce River Basin that release effluents into water bodies must submit a periodic statement of pollution load to the governing organization, according to the Normative Resolution number 74/2004 of COPAM (COPAM, 2004).

The Environment of Minas Gerais Environmental State Foundation (Fundação Estadual do Meio Ambiente de Minas Gerais-FEAM) obtained authorization for restricted use for the purpose of such studies. The database of the Doce Basin pollution load statements is included since the pollution load statement is mandatory for projects subject to environmental licensing in the state. However, it was found that the water quality parameters of interest - BOD, COD, TSS, $\mathrm{N}_{\text {ammonia }}$, and $\mathrm{P}_{\text {total }}$ - were not always present in such statements after the tabulation and verification of all the extensive material. There is a mismatch of information between the database offered by ANA and FEAM. So, we opted only for the simulation of the sanitation sector, and the specialized literature data were used to estimate the concentrations of water quality parameters.

It was found that this procedure can be used without problems for the sanitation sector, since the sewage characteristics (raw and processed) are well known in the literature (e.g. VON SPERLING, 2014; JORDÃO; PESSÔA, 2014). Therefore, typical concentration values of the chosen parameters - raw and processed sewage - were used for the analysis (VON SPERLING, 2014).

It was noted that for effluents from other sectors the use of literature data to determine load characteristics would be impossible, since the quality of effluents emitted by the same segment developments may vary with the amount of raw material processed, process technology, and conditions operational.

To define the price of reference units established in each of the proposed alternative charging methods, the unit price list currently used in the Doce River Basin was considered, referring to Deliberation CBH Doce number 26, from March 31, 2011. The conversion of the current unit price ( $\mathrm{kg}$ BOD released) for units of the alternative proposals is presented here, and the procedure is reported below.

To carry out the simulation work, the concentration limit (CL) of Class 2 frame was considered.

In both proposals, it must be highlighted that for both the total phosphorus parameter and the ammonia nitrogen parameter the best condition for the user was considered, i.e. the highest concentration established in Resolution CONAMA number 357/2005 (CONAMA, 2005).

In the specific case of phosphorus, the value should be considered consistent with the local condition in order to avoid problems with the development of cyanobacteria in water as the standards depend on the water flow rate (lotic or lentic environment). In the case of ammonia nitrogen, the water $\mathrm{pH}$ should be considered. This is because when the $\mathrm{pH}$ is basic, it allows for conversion of ammonium ions into ammonia gas, which is toxic to fish. 


\section{Definition of PPU for simulations}

To make the simulations for potential charging proposals, a PPU was defined for each of the units (PE and $\mathrm{m}^{3}$ ). Taking into account the current charging system in the Doce River Basin, exposed PE was defined as relating to PPU in the following manner.

Whereas von Sperling (2014) shows that the typical contribution per capita BOD sanitary sewer is in the order of $50 \mathrm{~g} \mathrm{inhab}^{-1} \mathrm{~d}^{-1}$. In a year, this contribution would be $18.25 \mathrm{~kg}_{\text {inhab }}{ }^{-1}$. Knowing that for the year 2012, $\mathrm{R} \$ 0.100$ per kilogram of BOD released was charged (CBH-DOCE, 2011), a resident would pay, then, equivalent to $\mathrm{R} \$ 1.825$ per year. Thus, the PPU corresponding to $\mathrm{PE}$ is $\mathrm{R} \$ 1.825$.

The value of PPU for a cubic meter of water was adopted as a tenth of the amount charged in 2012 by the same volume of sourced water (CBH-DOCE, 2011). This is an arbitrary value, as it could not be considered the same value. It is not per cubic meter sourced because the water is not removed/taken up the course, but actually being used in the riverbed. In addition, the stream has a potential depuration, which should, therefore, compensate for the overestimation of the affected volume of water. Thus, this volume may be used downstream depending on the potential of self-purification or, especially, the quality of water needed.

Therefore, the PPU corresponding to one $\mathrm{m}^{3}$ of water for dilution was considered $\mathrm{R} \$ 0.0018$.

It is noteworthy that these values are merely established with simulations of storage potential of the proposals. These were considered for comparison purposes with the amount collected using the current method in use, as the basin committees have the role of deciding the prices to be charged for water use.

\section{Simulations of hypothetical treatment scenarios}

Financial constraints, as well as political will, are barriers to the implementation of sanitation and sewage treatment systems necessary for environmental restoration and maintenance of public health (VON SPERLING; CHERNICHARO, 2002). However, steps should be taken with the given population socioeconomic conditions participating in this development so that the distance between the desirable and achievable and between the law and reality do not continue broadening (VON SPERLING; CHERNICHARO, 2002). Changes are needed, and the first step is to increase the awareness of all users in the sector through the generation of more concrete information.

To this effect, scenarios considering different levels of treatment have been proposed, and then new simulations for the water charging were made for the proposals of alternative mechanisms.

For this, three levels of treatment were considered: primary, secondary, and tertiary. For the first level, it was considered that $100 \%$ of the sewage was treated in conventional primary treatment (Scenario 1). In the second level, $50 \%$ of treated sewage was treated in anaerobic (UASB) reactor followed by a trickling filter (Scenario 2), as this type of solution has been adopted more often by the Sanitation Company of Minas Gerais (COPASA) for projects in recent years. As for the third scenario, $50 \%$ of treated sewage in UASB followed by polishing ponds was considered (Scenario 3).

To perform the simulations, the typical removal efficiencies of the main pollutants of interest in domestic sewage were adopted from reports in the corresponding technical literature (VON SPERLING, 2014).

\section{RESULTS AND DICUSSION}

\section{Selected water quality parameters}

The current charging method for the assimilation of wastewater in the Doce River Basin is based only on annual organic load released, measured in terms of Biochemical Oxygen Demand (BOD).

This parameter is very significant when treating biodegradable waste with a high organic load such as those arising from the food industry and animal breeders, for example. However, BOD load alone is not what best characterizes/ quantifies the volume of water of the water body which will be compromised by the activity when treating the effluents from a textile factory, a tannery, the paper and cellulose industry, or the chemical industry.

These types of enterprises generally emit wastewater with high load of non-biodegradable compounds and, therefore, are quantified in COD analysis and not in BOD. The COD does not only quantifies the non-biodegradable fraction but also quantifies the biodegradable fraction. Thus, the COD is the sum of BOD and a non-biodegradable portion of the organic matter.

Another point to be considered is the fact that some activities in the Doce River Basin - papermaking and paper, textiles, mining, fertirrigation, application of pesticides and agricultural supplements - emit significant concentrations of inorganic compounds (with emphasis on heavy metals) and organic compounds of difficult degradation (pesticides, dyes, hormones). These compounds are not identified in simple analyzes such as BOD or COD. However, it is necessary to monitor how much of these is released, as they are harmful to living beings. Even at low concentrations, they cause devaluation of water resources, especially when present in the fountain source supply as these become unviable activities. In terms of charging for the intrinsic value of the water, it can be said that it is like the BOD parameter in the way it consumes a portion of the volume that is available from the basin.

In addition, a major concern of the agencies responsible for watershed management is the excessive proliferation of cyanobacteria. According to ANA (2012a), excessive growth of algae in Brazilian reservoirs is a reality and has undermined the multiple uses of water.

This problem is a result of a phenomenon known as eutrophication, which is caused by increased nutrients in water bodies. These phosphorus and nitrogen nutrients are coming from anthropogenic water use such as sewage dilution without proper treatment to remove nutrients (tertiary treatment) and nitrogen and phosphate fertilizers. These nutrients leach to reach the water bodies and have the undesired eutrophic effect when combined with rising temperatures.

In a monitoring campaign carried out in 2011 by ANA, it was found that $68 \%$ of municipalities in the Doce River Basin 
throw raw sewage in federal water body (ANA, 2012a). In the report "Situation of Water Resources in Brazil - Report 2012", one can see that in Ipatinga and Governador Valadares the federal water body has some compromised qualities when comparing the qualitative and quantitative analysis of basin waters with the release/discharge condition of the sewage of the cities (ANA, 2012b). In this context, there were the troubling cyanobacterial bloom episodes in the Suaçuí sub-basin during November 2008 in the municipality of Governador Valadares. At the time, the cyanobacteria reached the mark of 91,336 cells $\mathrm{mL}^{-1}$ (ANA, 2012a).

As known, the release of raw sewage into water bodies leads to a concern with the monitoring of the parameters BOD, COD, nitrogen, and phosphorus. These last two are the main causes of excessive proliferation of cyanobacteria. Reynolds et al. (2002) suggest that there is a relationship between the associations of these organisms and the size of the lake, mixing regime, nutrients, light availability, and carbon, among other factors.

Some species of cyanobacteria produce secondary metabolites that can give unpleasant taste and odor to water, in addition to dangerous toxins called cyanotoxins. These substances cause serious damage to animals that ingest or come in contact with contaminated water. The cyanotoxins can be classified according to the mechanism of action, as hepatotoxic, neurotoxic, dermotoxic, or promoting inhibition of protein synthesis (CARNEIRO; LEITE, 2007).

All these parameters discussed - BOD, COD, inorganic compounds, nutrients, and organic compounds that are difficult to degrade - add to the solids loading present in water. However, it is also very important to know how much is released into waterways because some inert material or any other substance that was for some reason not included among the above parameters, will also require a volume of water for dilution.

In Minas Gerais, in particular, attention should be given to the concentration of suspended solids. According to ANA (2012a) the iron ore exploitation is the largest source of waste with potential important impacts on the quality of water in this state. This is possibly caused by an increase in suspended solids or by chemical alteration of water in settling ponds used in ore processing.

In environmental and economic terms, the importance of quantifying solids that are released should be considered because presence of these solids in the water can cause damage to industrial equipment, irrigation equipment, in addition to health hazards, hindering the use of water.

Based on the analysis of the water quality parameters, the experiences of other countries, and the current management systems in Brazilian basins, it appears that the parameters BOD, COD, TSS (total suspended solids) $\mathrm{N}_{\text {ammonia }}$ (ammonia) and $\mathrm{P}_{\text {total }}$ (total phosphorus) broadly characterize the effluent released in the water in qualitative terms. Not only do they include the main parameters that are outside the standard range in the Doce River Basin as mentioned above, but they also provide a good view of how much is changing in the quality of receivers and, especially, the demanded volume for the dilution of the effluent.

In the report "Monitoring of surface water in MG Executive Summary" from 2012, it was found that the total ammonia nitrogen is one of the parameters associated with the occurrence percentage of medium and high toxic contamination incidence in the state of Minas Gerais. In 2012, this was mainly due to elevated concentrations (IGAM, 2013). This fact may justify the choice of this nitrogen form and not another like nitrate or nitrite, for example. However, it is emphasized that the choice of parameters, in general, was based on a broader analysis over a longer period using data from Consórcio Ecoplan Lume (2010).

\section{Alternative charging mechanisms}

Currently, the charged unit is per kilogram BOD released into the Doce River Basin, as well as in several other Brazilian basins; however, this unit cannot be fully understood by all users. Thus, it is of interest to choose an alternate unit.

Some countries adopt a corresponding pollutant load unit for a population equivalent to charge for the release of pollutant loads in waterways. For example, the Netherlands uses the population equivalent, and Germany uses a toxic or toxicity unit (SANTOS, 2002).

The unit of toxicity can be understood as a load corresponding to each parameter (BOD, phosphorus, nitrogen), which when released in the water body will cause the same toxic effect. The equivalent inhabitant, or local equivalent, or equivalent population (PE) is theoretically pollution generated by an inhabitant per day. This concept is generally used when one wants to estimate the number of people that would produce the same polluting load of a particular industry, organic pollution being the primary reference parameter.

According to Ramos (2003), the adoption of this type of unit allows the conversion of wastewater of different qualitative and quantitative compositions to compare on the same base. In addition to its simplifying effect, this indicator is also emphasized because it has an educational effect for the general public. It can demonstrate the equivalence of a pollution source and pollutant load provided by a number of people. Ramos (2003) also states: "To say that the factory 'A' releases ' $n$ ' kilograms of BOD per day may mean nothing to a layman, but to say that the 'A' factory pollutes as much as a community with ' $\mathrm{x}$ ' inhabitants can give a clearer idea of the environmental impact of that activity. "

By contrast, another method for qualitative charging, fully consistent with the guidelines of Law 9.433 / 1997, is that the water charge is made based on the volume of water to be compromised. That is, the charge shall be made in terms of cubic meters of water that are released and will be "consumed" for the occurrence of assimilation. According Porto (2002) cited by Rodrigues (2005), charging for the use of water as the used volume is the correct approach because it standardizes the unit to be charged. It also emphasizes that it is a difficult deployment system, but it is easier for the management of the basin as the balance availability or demand can be made directly. As a complement, it can be considered that this unit has the advantage of being in accordance with the principle of charging for "committed/compromised volume" and not for the pollution itself. In other words, water charge can be made for the intrinsic water use, and not pollution. The charge will be paid for the water that is being compromised/used, not the pollution that is being emitted. 


\section{Simulation for the sanitation sector}

Proceeding to the simulations for the amount that would be collected at the state and federal level if the proposals were implemented and analyzing the results for the sanitation sector (Figure 2), increases in the amounts collected are observed.

There is an increase of approximately $64 \%$ in the amount charged by the LPE proposal. It is believed that this increase in revenue will allow greater transfer to the managing bodies of the basin that may thus make greater investments in research and local actions to improve the quality of the provided resource. In turn, this would provide savings to users in the sector.

It is evident that the proposed LPE allows the calculation to become simple as there are five parameters to be compared on the same unit that is the population equivalent. The various parameters are made equivalent on the same base, being the pollution potential that an inhabitant puts in the water, and at the end, there will be one price: $\mathrm{PPU}_{\text {released }}$ per capita.

Using the proposal established with $\mathrm{CV}$, the amount charged shall be almost six times higher than the current value, which is an unrealistic value for the sanitation sector. This shows that this proposal is less acceptable, mainly from the user point of view. However, the value of a cubic meter used in the simulation cannot be what will be applied by management bodies as already mentioned. Thus, they may adopt more consistent values with more consistent assessment of the users.

The proposed CV would be interesting mainly because it standardizes the charging units. However, other factors should be considered thoroughly, which is the case for factors that influence the efficiency of depuration process.

Forgiarini et al. (2008a) presented a method of charging that was based on the dilution equation of BOD load, also considering some multipliers. For example, the multipliers include user type coefficient, type of source, type of use, among others. These are obtained from the dilution volume, sharing the BOD load by the concentration limit of the framework class. Proceeding in this way, any process of self-purification of the water body was also dismissed.

In the method used be Forgiarini et al. (2008a), there may have been an underestimation of the committed volume unlike the

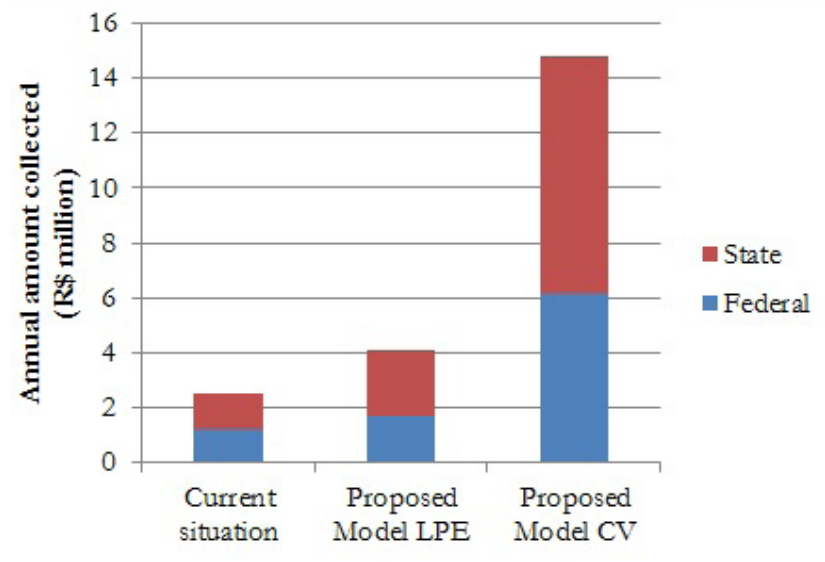

Figure 2. Simulation of the annual amount raised for the sanitation sector. proposal presented here, since the BOD is not a limiting parameter. Furthermore, the authors did not include naturally existing BOD load in the receiver stroke, creating a charge that was not part of the emitted load. In contrast, the proposal presented here may have overestimated the amount of dilution due to disregard of self-purification phenomenon.

However, simplicity and ease of understanding by the users will be compromised if this process is incorporated into a charging system for the use of water resources, as the self-purification is a complex process that requires further understanding.

For this reason, studies have already been developed in order to facilitate the calculation of the effluent dilution capacity considering the modeling of river water quality. As noted in the study by Teodoro et al. (2013), the simulation spreadsheet incorporates some equations to determine the flow dilution and charging for discharge of effluents. They did this to implement the concept of wastewater dilution capacity in the water quality model QUAL-UFMG.

For Ribeiro and Lanna (2003), some hypotheses could have been considered if they have not been conducted as specific studies on the purifying capacity of the water body. The self-purification of the effluent may occur (i) at the release point itself, (ii) downstream of the release point that does not occur in the release point and (iii) not at all along the watercourse. Thus, it can be said that considering situation (iii) promotes the environmental aspect, since it works within a range that ensures the maintenance of conditions framework class. From the user's point of view, however, this is disadvantageous and ultimately makes an actually available volume of water unavailable.

It is extremely important to point out that both proposals, LPE and CV, are of great versatility. Given a basin in which to implement these proposals, one must make the choice of relevant parameters concerning the quality of basin waters and subsequent conversion to the suggested units, LPE or CV.

In the simulation phase, one can observe how important the match parameter insertion was for the charge, because this parameter was responsible for the LPE in all cases for the sector under study. Therefore, the results indicate that the increase in the charged amount was because of the variable total phosphorus $\left(\mathrm{P}_{\text {total }}\right)$. If only the BOD parameter were considered in the calculation, the proposed PLA would show a reduction in the amount charged. This is because the proposal considers the background load off, that is, population corresponding to the equivalent load of organic material released (BOD) minus background load.

Given the above, it appears that discharging entities are treating their effluents at the secondary level (only removing part of the organic matter) and neglecting potential pollution. This, the phosphorus, is possibly one of the main factors responsible for episodes of high proliferation of algae and cyanobacteria in the Doce river watershed

A point worth emphasizing is that in the database provided by ANA, the enterprises and users currently being charged (managed charging in 2011/2012), include only companies and authorities responsible for sanitation of 55 municipalities. But according to Consórcio Ecoplan Lume (2010), the basin covers 230 municipalities, i.e. only $24 \%$ of municipalities (more precisely municipalities and sewage companies) are currently being charged. This shows that 
in addition to any change for the pricing model, there should also be concern for the scope of the charging or consideration for charging all or most of the basin. This is important because as stated above, the sanitation sector is of paramount importance in the qualitative aspect of the Doce River Basin waters.

Therefore, the importance of the sanitation sector in the Doce River Basin is clear. With respect to the issue of water quality, it can be said that the simulations were valid. Not only for the basin in question, but on the national level, the sanitation sector is shown to be extremely important in the management of water quality.

According to ANA, the main problem of water quality at the national level is the release of sewage in inland water bodies (ANA, 2005). According to the Atlas of Sanitation 2011, 55\% of Brazilian cities had sewage in 2008, but only $29 \%$ of Brazilian municipalities had installed a sewage treatment system. In the Southeast, $48 \%$ of municipalities offered sewage treatment on average (IBGE, 2011). The pollution caused by industrial and agricultural effluents, improper disposal of solid waste, and inadequate soil management also significantly contribute to the impairment of water quality in watersheds.

Considering the municipalities that reported pollution or contamination in water sourcing, the Atlas of Sanitation 2011 also indicates that in addition to pesticide waste and improper disposal of municipal solid waste, no treatment of sewage accounts for the following: $72 \%$ of pollution incidents and pollution of the water surface waters, $60 \%$ of shallow wells, and $54 \%$ of deep wells (IBGE, 2011).

Thus, it can be said that the simulations are quite representative at the national level as well.

\section{Simulations of hypothetical treatment scenarios}

Following simulation for the three treatments in Figure 3, a reduction in the amount to be paid for the sanitation industry scenarios can be seen. In most cases, the lower the released load, the lowest amount to be paid.

There is a decrease of approximately $17 \%$ in water charge considering the Scenario 1 treatment, and the same percentage reduction when considering Scenario 3. It can be inferred, then, that if the entire population of the Doce basin had access to treatment with a sewage system and all the collected sewage was treated at least at the primary level, it would have the same effect as if half of that sewage were treated at a tertiary level. This indicates that the initial deployment of a simpler system with a lower cost of implementation/operation would have very positive effects on the basin water quality. If the treatment set out in Scenario 2 was considered, this reduction would be smaller, being close to $3 \%$.

It should be considered that this reduction in the amount to be paid by companies and municipalities sanitation could be reversed by the construction and operation of their own treatment systems. This reduction also indicates that a lower pollutant load would be released into the Doce basin waters.

Again, one can note the importance of the introduction of total phosphorus in the proposed parameter, because in all the simulated treatment scenarios, this was the limiting parameter.

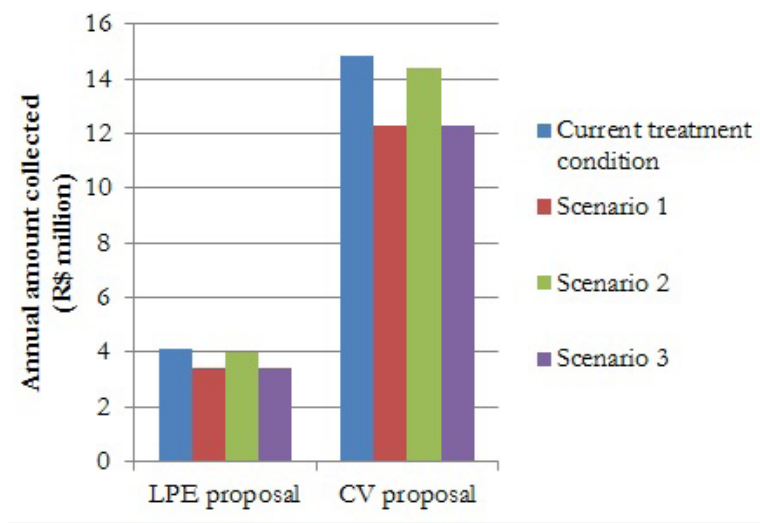

Figure 3. Simulation of the amount charged for the sanitation sector considering different treatment levels.

Implementation costs of conventional primary treatment are about \$35-65USD per capita. The annual costs of operation and maintenance $(\mathrm{OM})$ are $\$ 2-4 \mathrm{USD}$ per capita per year. For the UASB reactor system followed by a trickling filter, implementation costs are \$65-110USD per capita, and annual OM costs are \$5-10USD per capita. Finally, for the USAB system followed by polishing ponds, implementation costs are \$80-200USD per capita, and annual OM costs are \$3-6USD per capita (VON SPERLING, 2014). However, comparative analysis of the implementation cost and operation of treatment systems in addition to the amount to be paid has not been carried out. These were calculated according to the different methodologies proposed for the use of water for assimilating waste because the PPU values adopted in the simulations are not necessarily the same that are adopted for the basin. The possibility of proposing values that encourage the treatment of wastewater prior to discharge into the water body is expected.

In addition, the value of the PPU for release is based only on the BOD parameter. As there is a known impact on the quality of the water for each parameter in a given volume of water, one must choose a consistent value for such calculations.

Finally, it is important to note that this study looked only alternative mechanisms for charging for the use of water resources for assimilating waste. Proposed incentive for good practice were not evaluate. These practices would include less waste, more effective treatments - which does not impede what the management bodies do.

\section{CONCLUSIONS AND FINAL CONSIDERATIONS}

Based on the results obtained in this study, it can be concluded that:

Among the water quality parameters, BOD, COD, TSS, $\mathrm{N}_{\text {ammonia }}$ and $\mathrm{P}_{\text {total }}$ were the most relevant for the application of new charging mechanisms for use of water to assimilate effluents in the Doce River basin.

The new mechanisms contemplate more broadly the real problem of water quality in the Doce basin by considering parameters other than the BOD. Thus, the new methods represent a fairer way of charging, since they include consideration of the background load. 
Proposals for Limiting Population Equivalent (LPE) and Compromised/Commited Volume (CV) are highly versatile and can be implemented in any basin simply by the choice of parameters relevant to water quality in that basin. However, the Equivalent Population Limiting proposal was considered the easier application and more understood by users.

The simulations showed an increase in the amount charged by applying the new proposals. In the simulation for the proposed LPE, the $\mathrm{P}_{\text {total }}$ parameter was of paramount importance in managing the quality of Doce basin waters, showing a problem to be more widely studied.

The simulated treatment scenarios showed the importance of proper disposal of produced sewage. This was noted not only from an economic standpoint, representing a reduction of the amount to be paid, but also, above all else, from the standpoint of water quality.

It may also be noted how important the withdrawal of phosphorus systems could be if implemented. Only with this tertiary removal is the water quality going to change with the same load input in the systems.

Realizing the importance of the sanitation sector in the Doce River Basin in regards to water quality, it is concluded that the simulations were valid. However, a quantitative and, more importantly, consistent quality database should proceed with further parameter analysis to cover the different sectors.

\section{ACKNOWLEDGEMENTS}

This scientific work is based on the improvement of charging mechanisms for the Doce River watershed. It was conducted by FURNARBE, hired by IBIO AGB Doce in meeting the demand of CBH's that make up the said basin. The authors also thank CNPq, FEAM, and ANA. We would also like to thank Michael J. Stablein for translating this work.

\section{REFERENCES}

AMORIM, M. A. M.; CARVALHO, G. B. B.; THOMAS, P. T.; FREITAS, N. N.; ALVES, R. F. F. A Cobrança pelo uso de Recursos Hídricos na Bacia Hidrográfica do Rio Doce. In: SIMPÓSIO BRASILEIRO DE RECURSOS HÍDRICOS, 19., 2011, Maceió. Anais... Porto Alegre: ABRH, 2011. p. 1-14. Disponível em: http://www.abrh.org.br/ SGCv3/UserFiles/Sumarios/ceda8c2ef0a375e2b645402a911a0244_ ff299822aa956aed2ec1405b2f2d35ed.pdf. Acesso em: 12 dez. 2015.

ANA - AGÊNCIA NACIONAL DE ÁGUAS. Panorama da qualidade das águas superficiais no Brasil. Brasília: ANA, 2005. 176 p.

ANA - AGÊNCIA NACIONAL DE ÁGUAS. Relatório técnico: ocorrência de cianobactérias na bacia bidrográfica do rio Doce. Brasília: ANA, 2012a. 75 p.

ANA - AGÊNCIA NACIONAL DE ÁGUAS. Conjuntura dos recursos hídricos no Brasil: informe 2012. Brasília: ANA, 2012b. 215 p. Edição especial.
BRASIL. Lei Federal n . 9.433, de 08 de janeiro de 1997. Institui a Política Nacional de Recursos Hídricos, cria o Sistema Nacional de Gerenciamento de Recursos Hídricos, regulamenta o inciso XIX do art. 21 da Constituição Federal e altera o art. $1^{\circ}$ da Lei n ${ }^{\circ}$ 8.001, de 13 de março de 1990, que modificou a Lei $\mathrm{n}^{\circ}$ 7.990, de 28 de dezembro de 1989. Diário Oficial [da] República Federativa do Brasil, Brasília, DF, 8 jan. 1997.

CAMPOS, N.; STUDART, T. Gestão de Águas: princípios e práticas. Porto Alegre: Associação Brasileira de Recursos Hídricos, 2001. 197 p.

CARNEIRO, T. G.; LEITE, F. Cianobactérias e suas toxinas. Analytica, v. 5, n. 32, p. 36-41, 17 dez. 2007.

CBH-DOCE - COMITÊ DA BACIA HIDROGRÁFICA DO RIO DOCE. Deliberação CBH-DOCE n ${ }^{\circ} 26$, de 31 de março de 2011. Dispõe sobre mecanismos e valores de cobrança pelo uso de recursos hídricos na bacia hidrográfica do rio Doce. $C B H$ DOCE, Governador Valadares, 31 mar. 2011.

CERH/COPAM-MG - CONSELHO ESTADUAL DE RECURSOS HÍDRICOS DE MINAS GERAIS/CONSELHO ESTADUAL DE POLÍTICA AMBIENTAL. Deliberação Normativa no 26, de 18 de dezembro de 2008. Dispõe sobre procedimentos gerais de natureza técnica e administrativa a serem observados no exame de pedidos de outorga para o lançamento de efluentes em corpos de água superficiais no domínio do Estado de Minas Gerais. Diário do Executivo de Minas Gerais, Belo Horizonte, 30 dez. 2008.

CONAMA - CONSELHO NACIONAL DO MEIO AMBIENTE. Resolução CONAMA nº 357, de 17 de março de 2005. Dispõe sobre a classificação dos corpos de água e diretrizes ambientais para o seu enquadramento, bem como estabelece as condições e padrões de lançamento de efluentes, e dá outras providências. Diário Oficial [da] República Federativa do Brasil, Brasília, DF, 18 mar. 2005.

CONSÓRCIO ECOPLAN LUME. Plano integrado de Recursos Hídricos da Bacia Hidrográfica do Rio Doce e planos de ações para as unidades de planejamento e gestão de Recursos Hídricos no âmbito da Bacia do Rio Doce. Governador Valadares: Consórcio Ecoplan-Lume, 2010. v. 1, 478 p.

COPAM - CONSELHO ESTADUAL DE POLÍTICA AMBIENTAL. Deliberação Normativa COPAM no 74, de 9 de setembro de 2004. Estabelece critérios para classificação, segundo o porte e potencial poluidor, de empreendimentos e atividades modificadoras do meio ambiente passiveis de autorização ambiental de funcionamento ou de licenciamento ambiental no nível estadual, determina normas para indenização dos custos de análise de pedidos de autorização ambiental e de licenciamento ambiental, e dá outras providencias. Diário do Executivo de Minas Gerais, Belo Horizonte, 2 out. 2004.

FORGIARINI, F. R.; SILVEIRA, G. L.; CRUZ, J. C. Modelagem da cobrança pelo uso da Água Bruta na Bacia do Rio Santa Maria/ RS: I - estratégia metodológica e adaptação à bacia. RBRH: Revista Brasileira de Recursos Hídricos, v. 13, n. 1, p. 65-77, 2008a. http:/ / dx.doi.org/10.21168/rbrh.v13n1.p65-77. 
FORGIARINI, F. R.; SILVEIRA, G. L.; CRUZ, J. C. Modelagem da cobrança pelo uso da água bruta na Bacia do Rio Santa Maria/RS: II - aplicação em escala real e validação. $R B R H$ : Revista Brasileira de Recursos Hídricos, v. 13, n. 1, p. 79-89, 2008b. http://dx.doi. org/10.21168/rbrh.v13n1.p79-89.

IBGE - INSTITUTO BRASILEIRO DE GEOGRAFIA E ESTATÍSTICA. Atlas de saneamento 2011. Rio de Janeiro: IBGE, 2011. 268 p.

IGAM - INSTITUTO MINEIRO DE GESTÃO DAS ÁGUAS. Monitoramento da qualidade das águas superficiais em Minas Gerais em 2012. Belo Horizonte: IGAM, 2013. 47 p. Resumo Executivo.

JORDÃO, E. P.; PESSÔA, C. A. Tratamento de esgotos domésticos. 7. ed. Rio de Janeiro: ABES, 2014. 1050 p.

PINHEIRO, R. B.; MONTENEGRO, S. M. G. L.; SILVA, S. R.; MEDEIROS, Y. D. P.; AURELIANO, J. T. Outorga para lançamento de efluentes: uma metodologia de apoio à gestão de recursos hídricos. RBRH: Revista Brasileira de Recursos Hídricos, v. 18, n. 4, p. 55-65, 2013. http://dx.doi.org/10.21168/rbrh.v18n4.p55-65.

PORTO, M. Sistemas de gestão da qualidade das águas: uma proposta para o caso brasileiro, São Paulo. 2002. 131 f. Tese (Livre Docência) - Departamento de Engenharia Hidráulica e Sanitária, Escola Politécnica, Universidade de São Paulo, São Paulo, 2002.

RAMOS, M. Sustentabilidade do Sistema de Gestão de Recursos Hídricos no Brasil. In: FREITAS, M. A. V. (Org.). O Estado das águas no Brasil 2001-2002. Brasília: Agência Nacional de Águas, 2003. p. 437-446.

REYNOLDS, C. S.; HUSZAR, V.; KRUK, C.; FLORES, L. N.; MELO, S. Towards a functional classification of the freshwater phytoplankton. Journal of Plankton Research, v. 24, n. 5, p. 417-428, 2002. http://dx.doi.org/10.1093/plankt/24.5.417.

RIBEIRO, C. B. M. Sistema de alerta ambiental fundamentado em estudo teórico-experimental de transporte e dispersão de poluentes soliveis em cursos d'água. 2007. 168 f. Tese (Doutorado) - Departamento de Engenharia Agrícola, Universidade Federal de Viçosa, Viçosa, 2007.

RIBEIRO, C. B. M.; SILVA, D. D.; SOARES, J. H. P.; GUEDES, H. A. S. Warning system based on theoretical-experimental study of dispersion of soluble pollutants in rivers. Engenharia Agrícola (Impresso), v. 31, n. 5, p. 985-997, 2011. http://dx.doi.org/10.1590/ S0100-69162011000500016.

RIBEIRO, M. M. R.; LANNA, A. E. L. A outorga integrada das vazões de captação e diluição. $R B R H$ : Revista Brasileira de Recursos Hídricos, v. 8, n. 3, p. 151-168, 2003. http://dx.doi. org/10.21168/rbrh.v8n3.p151-168.
RODRIGUES, R. B. SSD RB - Sistema de Suporte a Decisão proposto para a gestão quali-quantitativa dos processos de outorga e cobrança pelo uso da água. 2005. 155 f. Tese (Doutorado) - Escola Politécnica da Universidade de São Paulo, São Paulo, 2005.

SANTOS, M. O. R. M. O impacto da cobrança pelo uso da água no comportamento do usuário. 2002. 241 f. Tese (Doutorado) - Universidade Federal do Rio de Janeiro, Rio de Janeiro, 2002.

SILVA, S. B. Cobrança pelo lançamento de efluentes: simulação para a bacia do rio Paraíba - PB. 2006. 177 f. Dissertação (Mestrado) Universidade Federal de Campina Grande, Campina Grande, 2006.

TEODORO, A.; IDE, C. N.; RIBEIRO, M. L.; BROCH, S. A. O.; SILVA, J. B. Implementação do conceito capacidade de diluição de efluentes no modelo de qualidade da água QUAL-UFMG: estudo de caso no Rio Taquarizinho (MS). Engenharia Sanitária e Ambiental, v. 18, n. 3, p. 275-288, 2013. http://dx.doi.org/10.1590/ S1413-41522013000300010.

VON SPERLING, M. Introdução à qualidade das águas e ao tratamento de esgotos. 4. ed. Belo Horizonte: UFMG, 2014. 452 p.

VON SPERLING, M.; CHERNICHARO, C. A. L. Urban wastewater treatment technologies and the implementation of discharge standards in developing countries. Urban Water, v. 1, n. 4, p. 105114, 2002. http://dx.doi.org/10.1016/S1462-0758(01)00066-8.

\section{Authors contributions}

Amanda Rodrigues Moreira de Oliveira: First author who contributed to literature review, proposal and simulation design, discussion of results, as well as writing and formatting of the article.

Alisson Carraro Borges: Corresponding author and principal advisor who contributed to the proposal design, obtaining the database of the responsible bodies, discussion of the results, and revision of the article.

Antonio Teixeira de Matos: Co-advisor on research who contributed to the discussion of the results and final review.

Demetrius David da Silva: Co-advisor on research who contributed to the development and review of the proposal as well as revision of the article.

Fernando Falco Pruski: Contributed to obtaining the database of the responsible bodies, improvement of the proposal, and revision of the article. 